Sit)

\title{
Analysis of Exchange Rate Pass-Through in Indonesia With VECM Approach
}

\author{
Nor Malisa ${ }^{1}$, Karsinah $^{2}$ \\ Jurusan Ekonomi Pembangunan, Fakultas Ekonomi, Universitas Negeri Semarang \\ Permalink/DOI: https://doi.org/10.15294/efficient.v2i2.30802
}

Received: December 2018 ; Accepted: March 2019 ; Published: Juny 2019

\begin{abstract}
The purpose of this research is to determine and analyze the degree of pass-through in Indonesia, which calculated from the cumulative response of the exchange rate to the CPI and the exchange rate on the exchange rate it self. Data used in this research is quarterly from $1997 Q_{3}$ to $2017 Q_{4}$. The variables used in this research are consumer price, rupiah to dollar exchange rate, producer price index, import price index, SBI interest rates, US wholesale price index. Data has sourced by Bank Of Indonesia and International Monetary Fund. The method used in this research is Vector Error Correction Model (VECM). The results showed that in the long-term exchange rate, producer price index, import price index, US wholesale price index had a positive effect on CPI while SBI interest rates had a negative effect to the consumer price. The impulse response function test states that in the first quarter only the variable itself was responded by the CPI, the second quarter import price index at the most by $1.2 \%$ was able to respond to the CPI. The results of the pass-through degree in Indonesia show that producer price is 0.009 and consumer price is -0.002. The result of variance decomposition shows that the import price index has the largest contribution in influencing the consumer price index. Have to reduce imports of raw materials for self-consumption, but have to import for re-export, so that domestic prices in Indonesia are stable.
\end{abstract}

Keywords: ERPT, Consumer Price Index, Import Price Index, VECM

\begin{abstract}
Abstrak
Tujuan penelitian ini untuk mengetahui dan menganalisis derajat pass-through di Indonesia yang dihitung dari kumulasi respon kurs terhadap IHK dan kurs terhadap kurs. Data yang digunakan dalam penelitian ini adalah data time series triwulan dari tahun 1997Q3 hingga 2017Q4.Variabel yang digunakan dalam penelitian ini antara lain indeks harga konsumen, nilai tukar rupiah per dolar, indeks harga produsen, indeks harga impor, suku bunga SBI, indeks harga perdagangan besar AS. Metode yang digunakan adalah Vector Error Correction model (VECM). Hasil penelitian menunjukkan bahwa pada jangka panjang variabel nilai tukar,indeks harga produsen, indeks harga impor, indeks harga perdagangan besar AS berpengaruh positif terhadap IHK sedangkan suku bunga SBI berpengaruh negatif terhadap IHK. Hasil uji impulse response function menyatakan bahwa pada kuartal pertama hanya variabel itu sendiri yang direspon oleh IHK, kuartal kedua indeks harga impor paling besar sebesar 1.2\% mampu direspon IHK. Hasil derajat pass-through indeks harga produsen sebesar 0.009 dan indeks harga konsumen sebesar -0.002. Hasil variance decomposition menunjukkan bahwa indeks harga impor mempunyai kontribusi terbesar dalam mempengaruhi indeks harga konsumen. Perlu mengurangi impor bahan baku untuk konsumsi sendiri, namun mengimpor untuk diekspor kembali supaya tingkat harga domestik di Indonesia stabil.
\end{abstract}

\section{Kata Kunci: ERPT, Indeks Harga Konsumen, Indeks Harga Impor, VECM}

How to Cite: Malisa, N., \& Karsinah, K. (2019). Analysis of Exchange Rate Pass-Through in Indonesia With VECM Approach. EFFICIENT Indonesian Journal of Development Economics, 2(2), 424-435. https://doi.org/10.15294/efficient.v2i2.30802

(C) 2019 Semarang State University. All rights reserved

\footnotetext{
Alamat Korespondensi :

Alamat: Gedung L2 Lantai 2 FE Unnes

Kampus Sekaran, Gunungpati, Semarang, 50229

E-mail : efficientjournal@gmail.com
} ISSN 2655-6197 


\section{INTRODUCTION}

Indonesia as a small open economy, the movement of exchange rates is one that can affect economic performance in general. UU No. 4 of 2003 states that Bank Indonesia as the central bank has one single goal, such to achieve and maintain the stability of the rupiah exchange rate. The condition of a country with an open economy, changes in exchange rates have an impact on the prices of consumers and producers (Savoie-Chabot and Khan, 2015).

According to Santosa (2012), the influence of exchange rate policy on the economy can be seen from two sides, there are the demand and supply side. The demand side aspect, happened when the rupiah exchange rate depreciates against the dollar, the amount of goods demanded by foreign countries will be increase than the number of imported demands. The supply side aspect, if the rupiah exchange rate depreciates, domestic supply will decrease because the amount of domestic demand has decreased due to the high price of imported goods (Santosa, 2012).

Drastic changes at the exchange rate will make it difficult for producers to get raw materials and capital goods that have high import content, which will have an impact on the cost of importing goods for the production process, which will affect the domestic price level which reflection of the inflation rate ( Langi, et.al, 2014).

The efforts made by domestic producers to cover import costs that are expensive are by increase the price of production goods, so that it will increases at the general price level. This phenomenon can be concluded that there is a positive relationship between the exchange rate and the inflation rate (Langi, et. $\mathrm{Al}, 2014$ ).
So, there is the movement of the rupiah exchange rate towards US dollar and inflation.

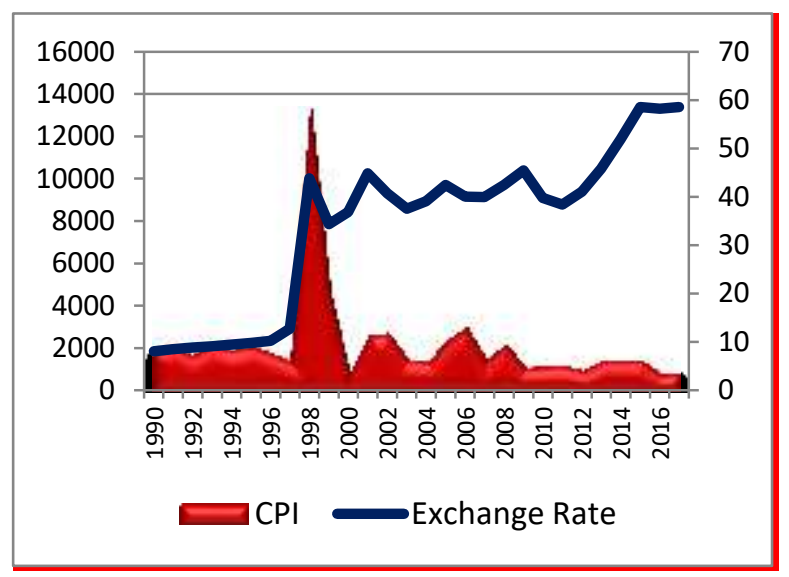

Figure 1. Movement Of The Exchange Rate Of $\mathrm{Rp} /$ \$ And The Indonesian Consumer Price Index 1990-2017

Source: International Financial Statistic, 2017

Based on data from Figure 1, it can be explained that the exchange rate of the rupiah against the US dollar during the implementation of the controlled floating exchange rate system until 1997 tended to be stable. But after the change of the free floating exchange rate system in 1997-2017, the exchange rate tended to weaken in 1998, 2000, 2005, 2009 and 2015. The factors causing the 1997-2005 depreciation were due to international economic conditions of influence from the United States which put pressure on the inflation rate from the price of imported goods and enlarge their financing (Bank Indonesia, 2005).

In 1997 when the rupiah exchange rate against the dollar depreciated the movement of inflation it tended to decline. Period 2000 when the exchange rate weakened but inflationary movements tended to decline. The same phenomenon occurred in 2004, 2006, 2009, 2012, 2015. In 2009 the exchange rate 
weakened to reach the level of $\mathrm{Rp} 11,980$ per dollar while inflation tended to depreciated.

In 2010 the exchange rate appreciated from Rp 9,18o to Rp 8,952 but inflation actually increased from $4.16 \%$ to $6.22 \%$. On 2010 period exchange rate has apreciated $\mathrm{Rp} 9.180$ to $\mathrm{Rp}$ 8.952 while the inflation increasing from $4.16 \%$ to $6.22 \%$. The inflationn on 1998 gain to $58 \%$, and $20 \%$ on 1999 period. This shows that global financial crisis brought unstability to the Indonesian economics especially to the price (Ulfa, 2012).

The relationship between exchange rates and inflation in that period did not support the theory of purchasing power parity and the opinion of McCharty (200o) who said that exchange rate depreciation increases the price of imported goods (consumption, capital and raw materials), which in fact will increase prices in domestic. This is not suitable or contrary to the theory of Purchasing Power Parity which states that there is a linear relationship between exchange rates and inflation.

During the financial crisis, Indonesia experienced the lowest growth among other countries has reached a negative value of $-14 \%$. Currency crisis experienced by countries in Asia in 1997-1998. The crisis that hit the Indonesian economy was the worst crisis compared to other countries affected by the crisis. Stability price and exchange rate is the key for recovery economy due to the crisis (Rahayu and Putri, 2017).

The depreciated of the rupiah exchange rate pushed up pressure on prices through increases in prices of imported goods. Annual report of Bank Indonesia In 1999 to 2002, the largest composition of Indonesian non-oil and gas imported goods was imported raw materials at 70 percent. The high cost of production, affect the increasing of price and decrease on the purchased and gain the inflation. The change in the exchange rate system carried out by the Indonesian government aims to maintain a balance of payments balance and maintain the negative impact of changes in exchange rates that will affect the Indonesian economy.

The decision of developing countries to adopt a free floating exchange rate regime and to focus of monetary policy on the determination of the inflation target in recent years has been studied by many economists, and the general view is that these choices bring important challenges to monetary policy, especially exchange rate pass through (ERPT) [(Goldbers and Knetter, 1996), and (Campa and Goldbers, 2002)].

Exchange rate pass-through (ERPT) represented as a change in price due to changes in one unit of the exchange rate that can change when the exchange rate regime has changed. The ERPT study has two transmission of price changes namely Incomplete Exchange rate pass-through occurs when changes in exchange rates are not followed by changes as large as changes in prices. That is, the importer does not raise the price of the goods as much as what happens or the exporter does not reduce the price of his export goods (in foreign currency) as much as what happens, while the complete passthrough get linear.

Research conducted by Ogundipe and Ito-sasaki and Sato (2005) who analyzed changes in exchange rates on consumer prices in developing countries showed that in the 
long run, there was a complete pass-through in Indonesia . Meanwhile, according to research results Villavicencio and Mignon (2017) which examined the change in the exchange rate on inflation in developing countries stated that Indonesia has a low degree of pass-through and negatives are incomplete pass-through of o039, the same result is obtained from research Carriere-Swallow ( 2016) shows the degree of pass-through in Indonesia of o.19.

The deep understanding of the Exchange Rate Pass-through becomes very important for several reasons: first, knowledge of Passthrough degrees and times is very important for the right assessment of the transmission of monetary policy at prices and for forecasting inflation. Second, the application of the inflation target requires knowledge of the size and speed of the exchange rate Pass-through to inflation. Finally, the Pass-through exchange rate has important implications for expenditure-switching effects of exchange rates.

Based on the background explanation described above, the research questions in this study can be formulated as follows:

1. What are the influence of changes in the rupiah exchange rate per dollar ( exchange rate pass-through), domestic Producer Price Index, Import Price Index, SBI Interest Rate, US Wholesale price index, on the Consumer Price Index in the short and long term in Indonesia during the $1997 \mathrm{Q} 3$ period -2017Q4.

2. What is the Consumer Price Index response to the exchange rate shock of the rupiah towards dollar, the domestic Producer Price Index, the import price index, the SBI interest rate and US Wholesale price index?
3. How does the contribution of each research variable on influencing the consumer price index?

4. What is the koefisien of the degree of pass through in each producer price index (PPI) and consumer price index (CPI)?

\section{METHOD}

This research quantitative using quarterly time series on $1997: Q_{3}$ to $2017: Q_{4}$ Quarterly Time Series. Variable used in thos research there are exchange rate, consumer price index, producer price index, import price index, SBI interest rate, US wholesale price index. The analytical method used in this study is Vector Error Correction Model (VECM) using E-Views 9 software. Must be passed in the VECM method Pre-Estimation consisting of unit root test / stationarity test, determination of optimal lag length, stability test and cointegration test. After the preestimation test is carried out, then the VECM test is carried out to see long-term and shortterm relationships. Impulse response function test to see the responses a variable due to other shock variables until some period after the shock. Next is the forecast error variance decomposition test to predict the contribution of the percentage variance of each variable due to changes in inflation in the system. Selection of equation models with the Vector Error Correction Model (VECM) method. The Model can be formulated as follows:

$$
\begin{aligned}
& C P I_{t}=\quad \beta_{0}+\beta_{10} C P I_{t-1}+ \\
& \beta_{11} \operatorname{LnER}_{t-1}+ \\
& \beta_{12} \text { PPI_IDN } N_{t-1}+\beta_{13} M P I_{t-1}+ \\
& \beta_{14} r S B I_{t-1}+\beta_{15} W P I_{-} A S_{t-1}+ \\
& \varepsilon_{1 t}
\end{aligned}
$$




$$
\begin{aligned}
& \operatorname{LnER}_{t}=\quad \beta_{0}+ \\
& \beta_{16} C P I_{t-1}+\beta_{17} L_{n E R_{t-1}}+ \\
& \beta_{18} P P I_{-} I D N_{t-1}+\beta_{19} M P I_{t-1}+ \\
& \beta_{20} r S B I_{t-1}+\beta_{21} W P I_{-} A S_{t-1}+ \\
& \varepsilon_{2 t} \ldots \ldots \ldots \ldots \ldots \ldots \ldots \ldots \ldots \ldots \ldots \ldots . . .(2) \\
& \text { PPI_IDN } N_{t}=\beta_{0}+ \\
& \beta_{22} C P I_{t-1}+\beta_{23} L_{n E R_{t-1}}+ \\
& \beta_{24} P P I_{-} I D N_{t-1}+\beta_{25} M P I_{t-1}+ \\
& \beta_{26} r S B I_{t-1}+\beta_{27} W P I_{-} A S_{t-1}+ \\
& \varepsilon_{3 t} \\
& M P I_{t}=\beta_{0}+ \\
& \beta_{28} I H K_{t-1}+\beta_{29} L_{n E R_{t-1}}+ \\
& \beta_{30} P P I_{-} I D N_{t-1}+\beta_{31} M P I_{t-1}+ \\
& \beta_{32} r S B I_{t-1}+\beta_{33} W P I_{-} A S_{t-1}+ \\
& \varepsilon_{4 t} \text {. } \\
& r S B I_{t}=\quad \beta_{0}+ \\
& \beta_{34} I H K_{t-1}+\beta_{35} L_{n E R_{t-1}}+ \\
& \beta_{36} P P I_{-} I D N_{t-1}+\beta_{37} M P I_{t-1}+ \\
& \beta_{38} r S B I_{t-1}+\beta_{39} W P I_{-} A S_{t-1}+ \\
& \varepsilon_{5 t} \\
& \text { IHPB_AS } S_{t}=\beta_{0}+ \\
& \beta_{40} I H K_{t-1}+\beta_{41} L n E R_{t-1}+ \\
& \beta_{42} P P I_{-} I D N_{t-1}+\beta_{43} M P I_{t-1}+ \\
& \beta_{44} r S B I_{t-1}+\beta_{45} \text { WPI_AS }{ }_{t-1}+ \\
& \varepsilon_{6 t}
\end{aligned}
$$

The method of calculating the degree of pass-through in this study refers to the model of Hyder and Shah (2004), McCarthy (2006) and Ito (2005) The degree of pass-through is calculated based on the cumulative impulse response from the shock of the exchange rate on the CPI and shocks the exchange rate of the currency itself. As for the equation of the can be written as follows:

$$
\text { Degree of Pass }- \text { Through }=\frac{\sum_{i=1}^{n} \varphi_{E R}^{c p i}}{\sum_{i=1}^{n} \varphi_{E R}^{E R} . .(7)}
$$

$\sum_{i=1}^{n} \varphi_{E R}^{C P I}=$ response cumulative of CPI toward exchange rate shock from the first to $\mathrm{n}$ $\sum_{i=1}^{n} \varphi_{E R}^{E R}=$ response cumulative of exchange rate shock toward exchange rate itself

\section{RESULTS AND DISCUSSION}

VECM Pre-Estimation Tes (Stationarity Test)

Where the CPI is the consumer price index (\%), LnER is the natural logarithm of the rupiah exchange rate per US dollar (rupiah), PPI_IDN is Indonesia's wholesale price index (\%), MPI is the import price index (\%), rSBI is the SBI interest rate (\%), WPI_AS is the United States wholesale price index (\%) $\beta_{0}$ is the intercept factor, $t-i$ is optimal lag, $\beta_{10}$ to $\beta_{45}$ to are regression coefficients and $\varepsilon_{1 t}$ to $\varepsilon_{6 t}$ is an error term.
Stationary test method that used in this research is the Philips-Perron test with five percent level, if the absolute value of statistical PP is greater than the critical value then the observed data show stasionarityy, and when the absolute value of statistical PP is smaller than the critical value then shows that data is not stationary. 
Table 1. Results of Phillips Perron Root Test

\begin{tabular}{|c|c|c|c|c|c|c|c|c|}
\hline \multirow[b]{2}{*}{ Variable } & \multicolumn{4}{|l|}{ Level } & \multicolumn{4}{|c|}{ First Difference } \\
\hline & Adj t-statistic & $\begin{array}{l}\text { Critical } \\
\text { Value }\end{array}$ & Prob & Adv. & $\begin{array}{l}\text { Adj t- } \\
\text { statistik }\end{array}$ & $\begin{array}{l}\text { Critical } \\
\text { Value }\end{array}$ & Prob & Adv. \\
\hline CPI & -2.406839 & -3.466248 & 0.3734 & $\begin{array}{l}\text { Non } \\
\text { Stasionary }\end{array}$ & $\begin{array}{l}- \\
6.247707\end{array}$ & -3.466966 & $\begin{array}{l}0.000 \\
0\end{array}$ & Stasionary \\
\hline LnER & -3.287318 & -3.466248 & 0.0757 & $\begin{array}{l}\text { Non } \\
\text { Stasionary }\end{array}$ & $\begin{array}{l}- \\
7.051435\end{array}$ & -3.466966 & $\begin{array}{l}0.000 \\
0\end{array}$ & Stasionary \\
\hline PPI_IDN & -1.710658 & -3.466248 & 0.7376 & $\begin{array}{l}\text { Non } \\
\text { Stasionary }\end{array}$ & $\begin{array}{l}- \\
7.06083 \\
4\end{array}$ & -3.466966 & $\begin{array}{l}0.000 \\
0\end{array}$ & Stasionary \\
\hline MPI & -1.661134 & -3.466248 & 0.7594 & $\begin{array}{l}\text { Non } \\
\text { Stasionary }\end{array}$ & $-3 \cdot 522119$ & -3.466966 & $\begin{array}{l}0.043 \\
8\end{array}$ & Stasionary \\
\hline Rsbi & -2.889553 & -3.466248 & 0.1714 & $\begin{array}{l}\text { Non } \\
\text { Stasionary }\end{array}$ & $\begin{array}{l}- \\
7.007579\end{array}$ & -3.466966 & $\begin{array}{l}0.000 \\
0\end{array}$ & Stasionary \\
\hline WPI_AS & -1.725297 & -3.466248 & 0.7310 & $\begin{array}{l}\text { Non } \\
\text { Stasionary }\end{array}$ & $\begin{array}{l}- \\
5.988221\end{array}$ & -3.466966 & $\begin{array}{l}0.000 \\
0\end{array}$ & Stasionary \\
\hline
\end{tabular}

Sourced: results of researchers data processing (2018)

Table 1. shows that the stationarity test in this research, a lag length of four is results at the level all variable has not selected. stasionary. Then after testing the first difference, all variables are declared stationary at a significance level of $1 \%, 5 \%$ and $10 \%$.

\section{Lag Test Optimal}

One of the most important things that needs to be done before estimating in a VAR / VECM model that is stationary at the level of first difference is determining the lag length . The optimal lag determination criteria is determined based on the shortest lag of the smallest Akaike Information Criterion (AIC) standard.

Based in the table 2, the results of the optimal lag test indicate that the Akaike Information Criteria (AIC) approach refers to the level of lags in four. Therefore, to do VAR /VECM estimation Table 2. Lag Length Test Results

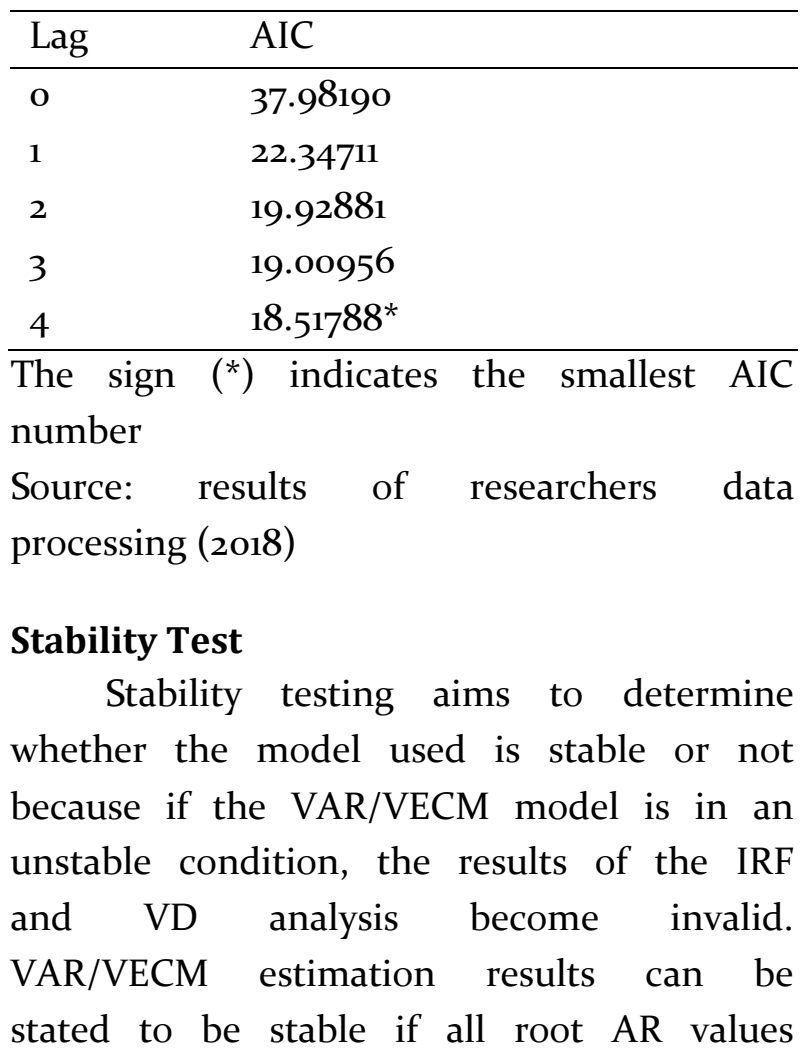


have modulus values smaller than one and all results points of Inverse Roots of AR Characteristic Polynomials are in unit circles. Figure 2 results of stability testing show that the VAR / VECM model to be estimated has been stable and valid because all Inverse Roots of AR Characteristic Polynomial results are within the unit circle so that the VAR / VECM model is valid for analysis of Response Function and Variance Decomposition.

Figure 2. VAR / VECM System Stability Test Results

Inverse Roots of AR Characteristic Polynomial

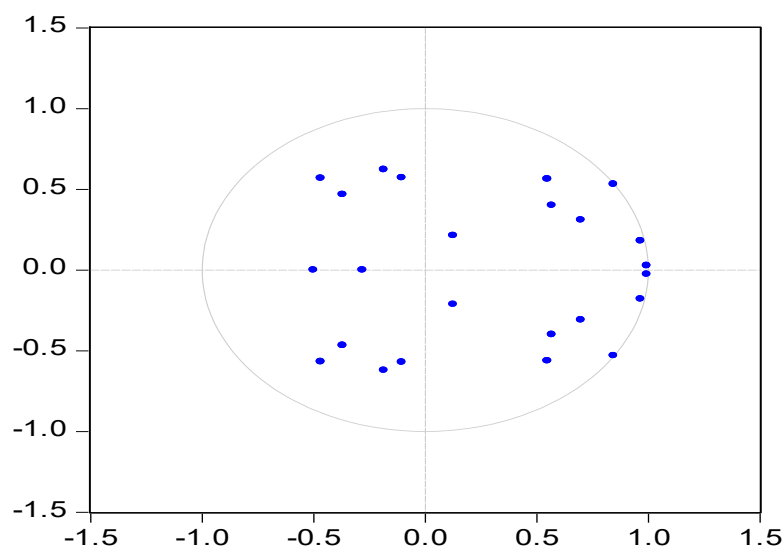

Source: Results of data processing E-views 9

\section{Cointegration Test}

Cointegration testing in research is based on data that is not stationary at the level but is stationary at the level of first difference. In addition, cointegration tests are carried out to determine the method to be used. If it is proven to be cointegrated, the method used is VECM, whereas if it is not cointegrated, the method used is VAR. This study uses the Johansen cointegration test . This cointegration test is done by looking at the estimated value of the trace statistics compared to the value of the critical value using a critical value of five percent. If the trace statistic value is greater, so the equation has cointegration.

The cointegration test results in Table 3 on the probability of trace statistic values indicate the existence of cointegration. This indicates that have long-term relationship between the variables, so the methods used in the research model ERPT is VECM method.

Table 3. Cointegration Test Results

\begin{tabular}{lll}
\hline Trace Statistic & Critical Value & Probability \\
\hline 277.2345 & 159.5297 & 0.0000 \\
202.9218 & 125.6154 & 0.0000 \\
143.0591 & 95.75366 & 0.0000 \\
87.99578 & 69.81889 & 0.0009 \\
40.52197 & 47.85613 & 0.2044 \\
17.48004 & 29.79707 & 0.6046 \\
6.446704 & 15.49471 & 0.6427 \\
1.832996 & 3.841466 & 0.1758 \\
\hline
\end{tabular}

Source: Obtain data E-views

\section{VECM Estimation Results}

The VECM estimation on the model was significant if the value of the t-statistic value is greater than the t-table value of 1.66515. The long-term influence on the rupiah exchange rate towards dollar variable, the producer price index, the import price index, the SBI interest rate, the US wholesale price index influences significantly on inflation. The short-term estimation results are only consumer price index variables, producer price index, SBI interest rates which have a significant effect on inflation. 


\section{Impulse Response Function}

The Impulse Response Function (IRF) analysis in the Vector Error Correction Model (VECM) describes the response of one endogenous variable to change shocks by one standard deviation in all endogenous variables in the VECM system. According to Widarjono (2016: 339), the IRF can track the response of endogenous variables in the VAR system because of the shock in the interference variable.

IRF analysis is used to determine the response of an endogenous variable to shock from one variable to another, and how long (period) influenced (Nugroho, 2009). Impulse Response Function examine the impact of the variable shock itself, the rupiah exchange rate toward dollar, the import price index, the producer price index, the SBI interest rate, and the US wholesale price index against the consumer price index response for the next 82 quarters.

The Impulse Responses Function (IRF) Test results show the impact of the CPI variable shock itself, the rupiah exchange rate towards dollar, the producer price index, the import price index, the SBI interest rate, the US wholesale price index. At the beginning of the quarter it was found that only the shock caused by the CPI itself was able to respond by inflation by $1.7 \%$, while the shock caused by other variables in the model began to respond by inflation in the second quarter because variable shocks take time to influence other variables.

The results of the impulse response function in the second quarter showed variable exchange rate shocks of the rupiah per dollar, producer price index, import price index, SBI interest rate, the US wholesale price index began to be responded to by CPI inflation. The fastest response and the highest variable CPI inflation is indicated by the shock of the import price index variable of $1.2 \%$ in the second quarter.

the exchange rate shock was responded negatively by inflation until the third quarter of $-0.5 \%$, in the quarter the IRF response rate showed the lowest point of movement, the negative influence of the rupiah exchange rate only lasted for 6 quarters, after that it was known that in the quarter -7 the response to inflation again increased to $0.7 \%$ towards its equilibrium point in the 6oth quarter period of $0.05 \%$.

The response to the inflation rate on shocks in the producer price index began to show a positive response in the second quarter of $0.3 \%$, then the movement increased until the fourth quarter experienced the highest response of $0.7 \%$. The 8 th quarter experienced its lowest peak of $-0.5 \%$ until the 2 oth quarter period began to stabilize below the balance line.

The inflation rate response to the shock of the import price index responded positively in the second quarter at $1.2 \%$, the trend increased then followed by an increase in the peak in the fourth quarter by $1.4 \%$, until the 26th quarter the movement tended to be stable. The shock of the import price index variable has an increasing trend and is responded to by the CPI inflation variable positively until the period ends. In general, the movements tend to be positively stable above the equilibrium line.

The IRF results show the response of the inflation rate to the new SBI interest rate shock began to show a positive response in the second quarter of $0.7 \%$, then it was discovered 
that in the 6th quarter the movement experienced a negative response of $-0.3 \%$. The response to CPI inflation to the variable shock of the US big trade price index was responded to positively by CPI inflation in the second quarter of $0.04 \%$. The increase was immediately responded negatively in the 3 rd period which was equal to -o.oo3. Variance Decomposition is a sequence of movement proportions caused by the presence of own shocks and other variables. According to
Widarjono (2016: 342) variance decomposition in Indonesia focused on how much the shock contribution of the variables used in the study is the exchange rate, producer price index, import price index, SBI interest rate and the US wholesale price index on inflation in Indonesia, so that will be forecast of what the variable has bigger contribution to the other variable, and that's be known through this variance decomposition

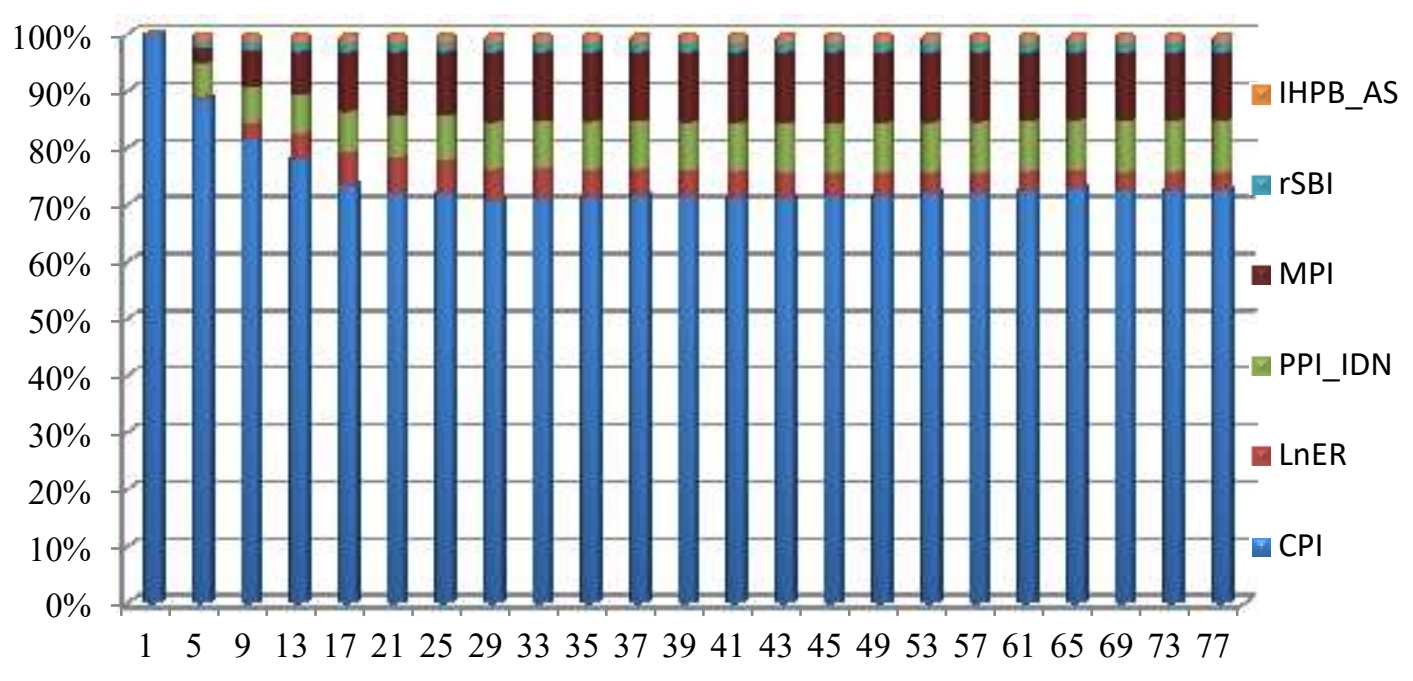

Figure 3. VECM Variance Decomposition Analysis Results

Source: results of processing E-views data

Based on Figure 3 the results of the analysis of variance decomposition indicate that the variable fluctuations in inflation in the first quarter were influenced by the internal shock of inflation itself of $100 \%$. In the first quarter there was no influence from other economic variables other than the CPI variable itself, because the factors that most influence CPI inflation are Inflation inertia. The result of inflation inertia is an indication that public expectations of inflation tend to be adaptive. Shocks caused by other variables in the model began to respond to inflation in the second quarter. In the $5^{\text {th }}$ quarter, the effect of CPI inflation itself decreased significantly to reach $84 \%$ and other variables explained its rupiah exchange rate, the domestic consumer price index of $5.5 \%$, index import price of $2.4 \%$, SBI interest rate of $1.3 \%$ and US wholesale price index of $1.15 \%$. In the fifth quarter the import 
price index was the variable that gave the biggest influence compared to other variables besides the variable of CPI inflation itself.

In the $45^{\text {th }}$ quarter period, the other variables explained their influence in the 41st quarter by $3.9 \%$ by the rupiah exchange rate towards dollar, the domestic price index of $7.7 \%$, the import price index of $11.2 \%$, the SBI interest rate of $1.5 \%$ and the US wholesale price index of $1.29 \%$. In this 45 th period, the import price variable is the variable that gives the greatest influence compared to other variables besides the CPI inflation variable itself.

The same thing happened in the 65th quarter period where the inflated variable influenced by the variable shock itself decreased to $68 \%$ and the variable that had the biggest influence then was the import price index which was $11.13 \%$. In the $77^{\text {th }}$ quarter, fluctuations in inflation are affected by other ariabel v explain its effect on the 77th quarter of $2.9 \%$ by the exchange rate rupiah towards dollar, the domestic wholesale price index amounted to $8.3 \%$, the import price index by $11 \%$, SBI interest rate of $1.6 \%$ and the US wholesale price index at $1.29 \%$.

The import price variable is the variable that gives the biggest influence compared to other variables besides the CPI inflation variable itself. The same thing happened in the 65th quarter period when the inflation variable influenced by the variable shock itself was reduced by 66.95 . Starting in the 37th quarter until the end of the 79th period forecasting, the influence value of the import price index increasingly dominates the inflation variable by $11.07 \%$ while the contribution of each variable is the rupiah exchange rate of $2.9 \%$, the producer price index of $8.3 \%$, SBI interest rates are $1.6 \%$ and the US wholesale price index is $1.29 \%$

\section{Degree of Pass-Through}

The degree of pass-through is calculated from the cumulative impulse response of the exchange rate shock to the CPI divided by the exchange rate shock against the exchange rate itself. The results of this analysis also answer the first and second aims of this study. The effect of accumulated exchange rate changes on the CPI was identified through 82 quarter pass-through rates.

Based on the test results, can be analyze that the CPI pass-through degree is $-0.002 \%$ which means that the degree of pass-through is delayed pass-through because the value is between 0 and - $1 \%$. Because of gradual price adjustments, this represents a high expectation about future inflation which ultimately increases the total exchange rate pass-through.

Negative pass-through indicates to encourage foreign cost shock because it can generate an increase in import prices at the same time as foreign policy reactions induce exchange rate appreciation (Adolfson, 2001). A negative pass-through of the price indicates that if the nominal exchange rate is appreciated, it will be followed by a decrease in price. Some structural breaks in inflation are often anticipated by each country, mostly passthrough declines due to changes in the regime of inflation determination (Jimborean, 2011). The producer price index pass-through degree has a value of $0.009 \%$, which means that the degree of pass-through is incomplete passthrough so that it can be concluded if the exchange rate depreciates by $1 \%$ it will increase the producer price index value by $0.009 \%$. 
Incomplete pass-through indicates the phenomenon of pricing to market, namely when the domestic exchange rate strengthens against foreign currencies (in this case US dollars) then exporters (to trading partner countries) using US dollars in trade with Indonesia) will do price intervention is to reduce the selling price. Theoretically, the structure imperfect markets allow pricing to market .

In these activities, agents are involved in import activities as well producers who carry out export activities can set margins the benefits. So that when there is a depreciation or appreciation, the magnitude changes in exchange rates that occur are not all transmitted to the selling price, but it is anticipated by setting profit margins, so that the increase prices are not as big as depreciation.

According to Bailiu and Hafedh (2004), the speed and expansion of changes in import prices are influenced by three things. There is an expectation of importers at the time of depreciation, so that importers maintain the same price in the event of changes in exchange rates.

There is an adjustment price, that is, if there is a change in the exchange rate, the importer does not necessarily increase the import price, because the adjustment cost of the increase in the price of the goods is greater than the increase in the goods themselves.

If the demand for imported goods is high during depreciation, the producer tries not to increase the price of the item because it will result in a decrease in demand for the item. If the shock of the exchange rate is only temporary, exporters take risks to reduce their profits, so that the increase in import prices is only a part of changes in exchange rates.

According to McCharty (2000) and Sato et al (2005), the pass-through of the Producer Price Index (PPI) has a direct effect when compared to the CPI (Producer Price Index). This indicates the greater amount of imported content, especially raw materials in a country, in the producer price index.

\section{CONCLUSION}

Based on the results research can be summarized as follows: (1) The variable has a positive effect on the CPI in the long term is the rupiah towards US dollar, the domestic wholesale price index, import price index and US wholesale price index. The variable that negatively affects the CPI is the SBI interest rate. Variables that influence the CPI in the short term are the CPI variable, the producer price index and the import price index.

(2) The Impulse Responses Function (IRF) test results show that the first period only the variable itself which is capable responded of $1.7 \%$, then the CPI quickly responds to changes in each variable in the second period after the shock occurred. The import price index shock is the strongest and highest at $1.2 \%$ accompanied by a positive pattern of movement until the end of the research period.

(3) The Variance Decomposition (VD) test result shows that in addition to originating from inflationary pressure itself, the contribution of the shock of the import price index variable is the largest variable in influencing the CPI and gives the average contribution that is relatively likely to increase over time. 
(4) The results of the calculation of passthrough degrees indicate that changes in exchange rates tend to be stronger against PPI than CPI, are incomplete pass-through with the Producer Price Index (PPI) of $0.009 \%$ compared to the Consumer Price Index (CPI) of $-0.002 \%$ because the large trade price index is a leading indicator.

Negative total pass-through to encourage foreign cost shock because it can generate an increase in import prices at the same time as the reaction of foreign policy to induce exchange rate appreciation. This implies that the change in the rupiah exchange rate per US dollar is not entirely transmitted to domestic consumer prices. The need to reduce imports of raw materials used for self-consumption, but to import semi-finished materials or capital goods whose products are used to reexport. Therefore, imported substitutes are needed in the country to reduce dependence, so that when import prices are high, there are cheaper substitutes so that production continues as usual.

\section{REFERENCES}

Bailliu, J., \& Hafedh, B. (2004). Exchange Rate PassThrough in Industrialized Countries. Bank of Canada Review, spring.

Berkala Ilmiah Efisiensi. Volume 14 no. 2 - Mei-44.

Campa, J. M., \& Goldberg, L. S. (2002). Exchange rate pass-through into import prices: A macro or micro phenomenon? (No. working paper 8934). National Bureau of Economic Research.
Hyder, Zulfiqar and Sardar Sah. (2004). Exchange Rate Pass-Through to Domestic Price in Pakistan. State Bank of Pakistan Working Paper No. 5, June 2004. International Monetary Fund. (2015). World Economic Outlook. IMF.

Ito T and Sato K. (2005). Exchange Rate Changes and Inflation in Post-Crisis Asian Economies : VAR Analysis of The Exchange Rate Pass-Through. National Bureau of Economic Research Working Paper 1235 .

Langi, Masinambow, Siwu. (2014). Analisis Pengaruh Suku Bunga Bi, Jumlah Uang Beredar, dan Tingkat Kurs Terhadap Tingkat Inflasi Di Indonesia. Jurnal

McCharty, Jonathan. (200o). Pass-Through of Exchange Rate and Import Prices to Domestic Inflation in Some Industrialized Economies. BIS Working Papers, 79Staff Reports, 111, Research Department Federal Reserve Bank of New York.

Nugroho, Sugeng M. Noor, Ibrahim dan Yanfitri. (2009). Dinamika Penawaran dan Permintaan Valuta Asing terhadap Nilai Tukar Rupiah dan Perekonomian. Buletin Ekonomi Moneter dan Perbankan.

Rahayu K., \& Putri, Phany Ineke. (2017). Mundell-Fleming Model: The Effectiveness of Indonesia's Fiscal and Monetary Policies. JEJAK: Jurnal Ekonomi dan Kebijakan. Volume 10 No.1 Hal 223-235. Semarang: Universitas Negeri Semarang.

Savoie-Chabot L, K. M. (2015). Exchange Rate PassThrough to Consumer Price: Theory and Recent Evidence. Bank of Canada Discussion Paper, 9.

Ulfa, Siti Aminah. (2012). Pengaruh Jumlah Uang Beredar, Suku Bunga SBI, Impor, Ekspor terhadap Kurs Rupiah/Dolar Amerika Serikat periode Januari 2006 sampai Maret 2010. Economics Development Analysis Journal. Volume 1 No.1 Hal 42-48. Semarang: Universitas Negeri Semarang.

Undang-Undang No 4 tahun 2003 tentang tujuan tunggal Bank Sentral.

Widarjono. (2016). Ekonometrika: Pengantar dan Aplikasinya disertai dengan Panduan E-Views. Edisi Keempat. Yogyakarta: UPP STIM YPKN. 